\title{
AGAMA DAN KEKERASAN MASSA
}

\section{Oleb M. Djunaidi Gbony}

\section{Penulis adalab Dosen tetap STAIN Malang dan Peserta Program Doktor IAIN Yogyakarta}

\section{A. Pendahuluan}

Semenjak pertengahan tahun 1996, sampai memasuki tahun 2000 ini, kekerasan massa (mass violence) menjadi salah satu warna sosiologis yang sangat mencolok dalam kehiclupan masyarakat kita. Beberapa peristiwa yang dapat disebut kembali misalnya peritiwa 27 Juli 1996, yang konon melebihi peristiwa Malari clua dekade yang lalu. Selanjutnya, secara beruntun terjadi beberapa peristiwa yang sejenis seperti yang terjadi di Situbondo, Tasikmalaya, Rengasclengklok, Pontianak dan Malaku

Semua rangkaian peristiwa di atas, mendorong berbagai kalangan mencari penjelasan secara lebih mendasar. Sebagian mencari penjelasan secara sosiologis, karena munculnya peristiwa kekerasan pada clasarnya bermata rantai dengan berbagai macam dimensi sosial yang terdapat dalam kehidupan masyarakat. Hal ini tidak berarti, bahwa apa yang ada clalam diri manusia sbagai inclividu tidak berperan terhadap munculnya kekerasan massa (mass violence). Mengikuti pemikiran Thomas Hobbes (1588-1679), dapat diungkap secara nyata daktor manusia yang clapat memicu terjadinya kekerasan massa. Dalam pandangan Hobbes, kekerasan merupakan keadlaan alami (state of nature) karena clalam cliri manusia terdapat dorongan-dorongan irrasional dan anarkistik serta mekanistik yang saling mengiri dan membanci sehingga menjadi kasar, jahat, buas, pendek pikir (Suseno, 1987:200-7).

Meskipun pandangan Hobbes di atas dapat clibenarkan secara ilmiah, tapi hal itu tidak serta merta dapat memunculkan praktek kekerasan, kalau tidak ada kekuatan impulsif yang datang clari luar individu. Apalagi, di samping kekuatan destruktif tersebut, dalam diri manusia juga terdapat kekuatan konstruktif. Bertolak belakang dengan pandangan Hobbes, Jean-Jacques Rousseau (17121778) mencitrakan manusia sebagai ciptaan yang polos, mencintai diri secara spontan, tidak egois. Hanya rantai peradabanlah yang telah membentuk manusia menjadi binatang yang memiliki sifat menyerang seperti keadaannya saat ini (Susno, ibid). Senada dengan Rousseau adalah pandangan Karl Marx (18181883). Marx menolak terhadap pandangan negatif bahwa clalam cliri manusia terdapat potensi yang dapat menggerakkan manusia dapat bertindak destruktif. Dalam pandangan Marx, manusia lebih banyak dibentuk oleh sejarah, khususnya perubahan-perubahan kondisi material manusia (Budiman: 1989:16).

Kesimpulan penting yang clapat ditarik dari clua pandangan yang saling bertolak belakang di atas adalah, perilaku manusia terbentuk melalui proses dialektika secara berkesinambungan antara apa yang ada dalam diri manusia, dengan kondisi eksternal manusia. Dalam wacana keilmuan kedua hal penting itu secara terpisah dicoba dipahami melalui 
pendekatan pikologis di satu pihak, agar clapat dipahami secara mendalam kondisi-kondisi internal yang clapat memicu terjadinya sebuah peristiwa yang bersifat sosial. Sedangkan di pihak lain, penghampiran sosiologis digunakan agar dapat dideskripsikan kondisi material (meminjam ungkapan Marx), dengan mana peristiwa dapat terjadi.

Tulisan ini lebih tertarik menggunakan penghampiran secara sosiologis dalam mencari penjelasan terjadinya berbagai kekerasan massa. Selanjutnya nanti akan difokuskan pada agama sebagai salah satu variabel penting yang perlu juga clilihat clalam setiap peristiwa kekerasan terjadi. Meskipun kekerasan bukan semata-mata dipicu oleh agama, tapi seringkali agama dimanfaatkan untuk memberi legitimasi. Anggapan seperti ini segera mengundang diskursus karena merefleksikan kenyataan paradoks dengan missi yang diemban oleh agama. Karena itu dalam konteks ini, agaknya perlu dipertegas tempat sosiologis, sehingga dengan mudah dapat dicleskripsikan kaitan agama clengan kekerasan.

Dalam kajian keagamaan, dikenal dua penclekatan, yaitu, penclekatan substantif, dan kedua, pendekatan fungsional (Abclurrahman, 1995:155). Pendekatan pertama dimulai dengan mencoba mempertanyakan apakah agama itu. Sedangkan yang kedua, memulai dengan pertanyaan apakah fungsi sosial clan psikologis agama, baik bagi individu maupun kelompok sosial. Jika dengan pendekatan pertama, dapat clibedakan mana yang agama dan mana yang bukan agama, maka clengan pendekatan keedua, dapat dicleskripsikan realitas agama yang memantul dalam struktur, sistem dan pengaturan sosial. Dalam penclekatan kedua ini, tidak lagi dipersoalkan ketentuan imperatif teologi agama bagaimana seharusnya realitas sosial dikonstruksi. Terhadap persoalan kekerasan, tidak perlu cliperclebatkan, apakah kekerasan itu merupakan penyimpangan dari doktrin agama atau tidak. Tapi yang perlu dieksplorasi lebih jauh terjadinya tali-temali antara kekerasan dengan agama.

\section{B. Kekerasan : Pendefinisian dan Beberapa Hipotesa Teoretik}

Di bawah ini akan dipaparkan pengertian kekerasan dan beberapa teori yang bisa saja masih bersifat hipotetik. Khusus tentang teori, tulisan ini lebih banyak merujuk pacla pemikiran kalangan pakar sosial di tanah air yang banyak memberikan analisis terhadap masalah kerusuhan sosial. Dengan cara ini, cliharapkan tulisan ini lebih bermakna secara empirik.

Kata kekerasan bersepadan dengan kata violence dalam bahasa Inggris. Sedangkan kata violence berkaitan erat dengan gabungan kata vis (daya, kekuatan) dan latus (yang berasal dari ferre, membawa) yang kemudian berarti membawa kekuatan (Windhu, 1992:62).

Dalam bahasa kita sehari-hari (Inclonesia), umumnya kekerasan dipahami hanya menyangkut serangan fisik belaka. Pengertian seperti ini agaknya telah menjadi semacam common sense. Lihat saja misalnya pengertian clari Robert Audi (dalam Windhu, ibid), yang merumuskan kekerasan sebagai serangan atau penyalahgunaan fisik terhadap seseorang atau binatang; atau serangan, penghancuran, perusakan yang sangat keras, kasar, kejam dan ganas atas milik atau sesuatu yang secara potensial clapat menjadi milik seseorang. Pengertian yang sama clapat kita baca dalam, The Harper Collins Dictionary Sociology (Jary \& Jary, 1991:545). Dalam buku ini kekerasan (violence) diartikan : the infliction of physical on the buman body, or buman property, by physical force using the body or weapons.

Pengertian yang sempit tentang kekerasan di atas ditolak oleh Johan Galtung, tokoh garda depan teori ketergantungan. Galtung clalam. memzhami kekerasan clilihat pada segi akibat atau pengaruhnya pada manusia. Karena clari 
sudut korban ini, kekerasan dalam pandangan Galtung tidak banyak bedanya apakah mati kelaparan merupakan akibat serangan militer yang berlarut-larut atau akibat ketidakadilan, ketidakmerataan, dan atau struktur vertikal dan simetris. Juga tidak ada bedanya seseorang dibunuh secara cepat dengan peluru atau mati pelan-pelan karena kekurangan makan (Windhu, op. Cit:65). Mengikuti pandangan Galtung ini, dengan demikian kekerasan mengandung cakupan yang luas, tidak hanya berupa kekerasan yang bersifat fisik, tapi juga psikologis, struktural dan kultural. Sejalan dengan ini, kita sering mendengar perbincangan tentang kekerasan budaya dan kekerassan struktural. Kalau kemudian kekeraan lebih banyak dilihat pada aspek fisik atau material, bisa jadi karena akibat dari kekerasan itu lebih banyak bersifat fisik atau material.

Lalu kenapa peristiwa kekerasan selalu muncul? Faktor-faktor apa saja yang menggerakkannya? Kenapa masyarakat kita, yang terkenal dengan semangat persatuan dan kesatuan serta semangat religius yang tinggi, tiba-tiba menjadi beringas? Kenapa nilai-nilai budaya dan keagamaan kehilangan fungsi integrasinya? Di bawah ini akan dicoba dikontruksi kembali beberapa teori yang kiranya dapat menjelaskan peristiwa kekerasan tersebut. Secara umum, jika ditarik benang merahnya, teori yang dipakai oleh beberapa pakar sosial berderivasi dari teori perubahan sosial. Dalam kerangka ini, kekerasan dipahami sebagai akibat lebih lanjut dari terjadinya perubahan sosial yang seringkali mendatangkan ekses negatif bagi kalangan tertentu.

Pertama kita mulai dari pemikiran Kuntowijoyo. Dalam tulisannya, Perubahan
Sosial dalam PJP I (1970-1995): Kerangka Analisis Sosial dan Historis (Suara Mubammadiyab, No. 4 Tahun ke-82), Kuntowijoyo memberikan suatu analisis yang sangat menarik tentang terjadinya perubahan sosial serta berbagai dampak sosial yang ditimbulkannya sepanjang pembangunan jangka panjang tahap pertama. Menurutnya, terdapat tiga kekuatan pengubah yang ekerja sepanjang PJP I, yaitu industrialisasi (diterapkannya organisasi, manajemen dan teknologi dalam produksi dan jasa); urbanisme (pertumbuhan menuju bentuk kota, perpindahan penduduk dari desa ke kota, dan dipakainya gaya hiclup kota oleh orang desa); dan internasionalisasi (hadirnya usahá -usaha internasional seperti LSM, Lion Club, Darul Arqam dan lain sebagainya).

Di antara tiga kekuatan di atas-meskipun saling melengkapi Kuntowijoyo memberikan tekanan pada industrialisasi yang dapat menimbulkan ekses negatif berupa terjadinya kekerasan. Dasar analisisnya adalah bahwa selama PJP I desa-desa telah berubah dari desa sosial ke desa ekonomi, ikatan-ikatan sosial melonggar. Pekerjaan off-farm menjadi bagian desa yang semakin penting. Makin dekat dengan kota perubahan sosial itu semakin teraisa. Industriindustri besar juga dibangun di kota dan dilokasi tersendiri yang ternyata menyebabkan dislokasi sosial. Mereka yang bekerja pada industri itu makin lama makin kehilangan basis agraris mereka menjadi proletariat tulen. Proletariat kota dan para pekerja non pertanian itulah, menurut Kuntowijoyo, yang apabila ada persoalan (pengangguran, penghinaan) mudah sekali menjadi emosional, punya collective bebavior, tidak harus digerakkan oleh pihak ketiga atau 
dikipasi.

Pemikiran Kuntowijoyo di atas clinilai oleh banyak kalangan lebih murni clibandingkan dengan analisis lain yang menggunakan teori konspirasi yang serba hitam putih clan simplikatif dalam melihat permasalahan. Teori ini sempat dimunculkan ketika terjadi kerusuhan di Situbondo dan Tasikmalaya, yang mengatakan kasus-kasus itu sebagai usaha mendeskreditkan sebuah organisasi keagamaan tertentu. Padahal, mengutip kembali pemikiran Kuntowijoyo, peristiwa yang terjadi di Situbondo dan Tasikmalaya serta peristiwa yang mendahuluinya, peristiwa 27 Juli 1996 di Jakarta, karena banyaknya pekerja nonpertanian yang menjadi anarkis karena mereka ticlak akan kehilangan apa-apa bila terjadi perubahan.

Masih dalam kerangka teori perubahan sosial, analisis berikutnya yang relevan dikonstruksi kembali adalah pemikiran Sunyoto Usman. Dalam tulisannya tentang, Agama dan Kekerasan Orang

Di antara tiga kekuatan di atas-meskipun saling melengkapi Kuntowijoyo memberikan tekanan pada industrialisasi yang dapat menimbulkan ekses negatif berupa terjadinya kekerasan. Dasar analisisnya adalah bahwa selarna PJP I desa-desa telah berubah dari desa sosial ke desa ekonomi, ikatan-ikatan sosial melonggar.
Kota (Suara Muibammadiyah, No. 4 Tahun ke82), Sunyoto Usman berpendapat bahwa munculnya kekerasan clalam masyarakat karena lebih berpengaruhnya faktor non-adaptive daripada faktor adaptive pada salat masyarakat sedang dilanda krisis nilai dan norma sosial. Nilai-nilai sosial yang telah lama disosialisasikan tidak lagi dipergunakan sebagai acuan dalam melakukan interaksi sosial. Demikian pula norma-norma sosial yang tidak mampu mengendalikan aran prilaku anggota masyarakat. Ketika itu, menurut sunyoto Usman, ada kekecewaan yang amat hebat karena berbagai harapan masyarakat baik yang berkaitan dengan pemenuhan kebutuhan ekonomi, politik maupun kultural tak clapat Ekspektasi nilai di sini cliartikan sebagai kondisi atau hal-hal yang mampu diraih dan dipertahankan.

\section{Agama, Integritas Sosial dan Kekerasan : Perspektif Struktur-Fungsional dan Konflik}

Dalam beberapa kasus kekerasan di tanah air, selalu ada kecenderungan baik disengaja atau tidak agama dilibatkan di dalamnya. Dari sini kemudian dimunculkan wacana konflik, kerusuhan dan kekerasan agama. Meskipun secara teologis keadaan ini dipandang sebagai bentuk paradoks, clalam realitas empirik atau ketika agama telah mewujud menjadi realitas sosial, kecenderungan ke arah itu sangat 
dimungkinkan terjadi sehingga agama kehilangan fungsi integrasi sosialnya.

Jika dipandang clari pespektif teori struktur fungsional, masyarakat pada clasarnya merupakan suatu equilibium sosial clari semua institusi yang ada di clalamnya. Sebagai keseluruhan sistem sosial masyarakat menciptakan pola-pola kelakuan yang terdiri atas norma-norma yang clianggap sah clan mengikat oleh anggotanya yang menjadi pengambil bagian clari sistem itu. Keseluruhan clari institusi-institusi yang membentuk sistem sosial itu sedemikian rupa, sehingga setiap bagian saling mengutungkan clengan semua bagian lainnya seclemikian erat hingga perubahan clalam satu bagian mempengaruhi bagian yang lain dan keadaan sistem sebagai keseluruhan (Henclropuspito, 1990:27). Agar masyarakat sebagai suatu sistem tetap survive dan tidak mengalami kekacauan di dalamnya, menurut Talcott Parsons (Ritzer, 1983:87), setiap lembaga yang ada dalam masyarakat perlu menjalankan fungsi pokok (functional imperative) apa yang kemudian disebut AGIL (Adaption, Goal Attainment, Integration, Latency).

Bagaimana agama memfungsikan clalam sistem sosial tersebut? Dalam perspektif struktur fungsional, agama dipandang mempunyai peran dalam menciptakan ikatan bersama baik cliantara anggota-anggota beberapa masyarakat maupun dalam kewajiban-kewajiban sosial yang membantu mempersatukan mereka (Nottingham, 1990:42). Fungsi seperti itu secara empirik telah dibuktikan oleh Emile Durkheim yang mengantarkan pacla suatu kesimpulan bahwa agama berfungsi sebagai kekuatan pemersatu masyarakat (Horton \& Hunt, 1993:306) Dalam, The Elementtry Form of Religious Life (1912), Durkheim menjelaskan bahwa tujuan agama adalah membantu orang berkomunikasi dengan sesamanya. Ritual-ritual religius yang dijalankan oleh setiap pemeluk agama membantu seseorang untuk mengembangkan rasa paguyuban (sense of community) seperti kebersamaan clalam peristiwa perkawinan, kematian dan lain sebagainya.

Durkheim mendasarkan analisisnya kepada laporan ahli-ahli antropologi yang meneliti orang-orang Aborigin Australia sampai ia meenemukan arti yang mendasar clari agama clalam masyarakat dimana masyarakat merasa perlu adanya pemupukan keakraban secara teratur yang melahirkan perasaan kolektif, membentuk kesatuan clalam kepribadian dan menghindari adanya kekerasan. Dari sini Durkheim melihat suatu fungsi yang mendasar clari agama yaitu sebagai perekat untuk menguatkan kelompokkelompok sosial yang ada dalam masyarakat dimana simbol-simbol agama akan tercermin clalam kehidupan mereka. Durkheim berpendapat bahwa individu manusia sebagai produk masyarakat membutuhkan norma-norma moral dalam kehidupannya serta kemampuan konseptual supaya menjadi manusia yang bermakna sebagaimana yang dikehendaki oleh agama.

Tapi kenapa dalam realitas sosial seringkali agama tidak fungsional seperti yang terlihat pada berbagai tinclak kekerasan? Dalam pandangan Durkheim (Burhanuddin, Kompas, Senin, 14 April 1997) keadaan ini bersumber clari kondisi masyarakat yang kesadaran kolektifnya yang diantaranya dibentuk oleh agama semakin mele- 
mah, di mana bidang-bidang kehidupan yang dikuasai oleh kesadaran kolektif semakin menyempit. Dan melemahnya kesadaran kolektif ini menurut Durkheim merupakan akibat dari pluralisme dan pembagian kerja yang semakin tajam. Tekanan dan pakssaan masyarakat trhadap individu semakin berkurang. Dengan demikian terdapat lebih banyak ruang gerak bagi perbedaan-perbedaan individu dan individualisme muncul menjadi semakin kental.

Akibatnya, inddividu-individu kehilangan pegangan dan terbongkar dari akarnya. Situasi semacam ini kemudian memperlemah ikatan sosial yang mempersatukan individu-individu dengan kelompok-kelompok sosial lainnya. Secara sosial hidup ini menjadi kurang berarti. Akibatnya perkembangan solidaritas sosial, yang merupakan pilar utama bagi kehidupan sebuah masyarakat, terancam. Keadaan sperti berpotensi memunculkan kekerasan yang bersifat sosial.

Di sisi lain, hilangnya kesadaran kolektif dan timbulnya kekerasan, pada dasarnya merupakan keadaan sosiologis yang tidak dapat dipungkiri karena dalam masyarakat, sebagaimana dalam pandangan teori konflik, selalu ditandai dengan persaingan yang mengarah pada terjadinya pertentangan atau konflik. Dijelaskan oleh Sanderson (1993:12) bahwa : (i) kehidupan sosial pada dasarnya merupakan arena konlik atau pertentangan di antara dan di dalam kelompok-kelompok yang bertentangan; (ii) sumber-sumber daya ekonomi dan kekuasaan-kekuasaan politik merupakan hal penting yang berbagai kelompok berusaha merebutnya; (iii) akibat tipikal dari pertentangan ini adalah pembagian masyarakat menjadi kelompok yang determinan secara ekonomi dan kelompok yang tersubordinasi; (iv) pola-pola sosial dasar suatu masyarakat sangat ditentukan oleh pengaruh sosial dari kelompok yang secara ekonomi merupakan kelompok determinan; (v) konflik clan pertentangan sosial di dalam dan di antara berbagai masyarakat melahirkan kekuatan-kekuatan yang menggerakkan perubahan sosial; (vi) karena konflik dan pertentangan merupakan ciri dasar kehidupan sosial, maka perubahan sosial menjadi hal yang umum clan sering terjadi.

Jika mengikuti gambaran Sanderson di atas, maka konflik dalam kehidupan sosial masyarakat nampak sebagai bentuk kekacauan. Karena itu oleh beberapa ilmuwan sosial konflik dianggap sebagai suatu yang clestruktif atau patologis bagi kelompok sosial. Akan tetapi Coser, justru memandang dari sisi lain. Dalam pandangannya, konflik memberikan sumbangan positif untuk membentuk serta mempertahankan struktur. Konflik dapat menciptakan dan menjaga garis batas antara dua atau lebih kelompok. Dan terakhir, konflik dapat memperkuat kembali identitas kelompok dan melindunginya agar tetap tidak lebur ke dalam dunia sosial sekelilingnya (Poloma, 1987:108).

Bagaimana agama dapat menjadi faktor konfliktual yang berakibat pacla munculnya kekerasan dalam masyarakat? Munculnya konflik dan kekeraan di mana agama seringkali dilibatkan di dalamnya, sbenarnya lebih merupakan sebagai akibat logis setelah agama mengalami proses pelembagaan secara sistimatik clan sisteemik. Dalam pelembagaan ini yang terjadi kemudian agama menjadi suatu kesadaran kelompok atau primordial yang bercampur dengan pembentuk kesadaran kelompok atau primordial lainnya seperti etnik, suku, kebangsaa, organisasi dan lain sebagainya. Jadi dengan demikian, agama di sini hanya dijadikan sebagai alat untuk kepentingan kelompok yang terlibat kekerasan.

\section{Penutup}

Dari uraian di atas dapatlah dipahami bahwa kendatipun agama memiliki seperangkat 
tata nilai dan moral yang dapat dijadikan pandangan hidup bagi masyarakat manusia, tetapi di pihak lain agama juga kadlang-kadang dapat menjadi pemicu konflik yang pada urutannya dapat menimbulkan kekerasan atau pun perselisihan yang meluas. Meskipun dalam batas tertentu, perselisihan itu sendiri mempunyai nilai positif dan negatif. Teori konflik dalam sosiologi keagamaan cenderung mementingkan peran slf-interest dalam perilaku manusia termasuk perilaku yang bersifat religius. Karena itu, clengan optimalisasi peran agama, kekerasan clan konflik dalam masyarakat dengan sendirinya dapat tereliminir atau diperkecil bahkan ditiadakan.

\section{DAFTAR PUSTAKA}

Djamari, Agama Dalam Prespektif Sosiologi, Departemen Pendidikan dan Kebudayaan Direktorat Jenderal. Pendidikan Tinggi, Proyek Pengembangan Lembaga Pendidikan Tenaga Kependidikan, Jakarta 1988.

D. Hendropuspito, Sosiologi Agama, Kanisius, Yogyakarta, 1990.

Elizabet K. Nottingham, Religion and Society. terj. Abclul Muis Naharong, Rajawali, Jakarta, 1990.

Franz-Magnis Suseno, Etika Politik, Gramedia, Jakarta, 1987.

George Ritzer, Sociology : A Multiple Paradigm, terj. Alimandan, Rajawali, Jakarta, 1985.

I Marsana Windhu, Kekuasaan dan Kekerasan Menurut Joban Galtung, Kanisius, Yogyakarta, 1992.

Karl Marx, The Economic and Philosophic Manuscripts of 1844, Internastional Publisher, New York 1964.

Keith A. Robert, Religion in Sociologycal Perspective, The Dorsey Press Homewood, Illionis, 1984.
Kuntowijoyo, Suaran Muhammadiyah, No. 4 Tahun ke-82.

L. Broom \& Philip Selznick, Dorothy Darroch, Sociology, Harper \& Row Publisher, New York 1981.

Margarett Paloma, Contempopary Sociologycal Theory, terj, Tim Yasogama, Rajawali, Jakarta, 1988.

Reace McGee, Sociology, An Introduction, Holt, Rinehart and Winstons, New York 1980.

Stephen K. Sanderson, Macrososiology, terj, Farid Wajdi, Jakarta, 1993.

Sunyoto Usman, Suaea Mubammadiyah, No. 4 tahun ke-82 